\title{
Implementation and Obstacles in The Execution of Warranties as Object of Liability Credit Rights in PT BPR Gunung Rizki Pusaka Utama Semarang
}

\author{
Eliza Chandradewi Arius ${ }^{1}$, Rya Rizqi Amalia ${ }^{2}$ and Sri Endah Wahyuningsih ${ }^{3}$
}

Abstract. Indonesia's economy is growing by leaps and bounds, where banking is very supportive financing of economic activities in order to meet the needs of Indonesian society. Each implementation agreement on bank credit, is always associated with the presence of collateral, the collateral which was born in the credit agreement is already an agreement between the parties to bind themselves to each other. Granting Mortgage is very important in the credit agreement for the lender has the right to the sale of goods as collateral. Aims to identify and analyze the execution of objects Mortgage as loan collateral at PT BPR Gunung Rizki Pusaka Utama Semarang and analyze the barriers that occur and solutions in the travel in overcoming these obstacles. The method used is the method of normative legal approach.

Execution of objects Mortgage as loan collateral at PT BPR Gunung Rizki Pusaka Utama Semarang do with Parate Execution. Where the execution of Encumbrance using Parate Execution aims to obtain repayment of its receivables efficiently and quickly. Barriers that occur in the implementation of the Mortgage object is the object of a third party guarantee, the collateral has not been registered, and the lack of good faith of the debtor.

Keywords: Execution; Mortgage; Security; Credit.

\section{Introduction}

Indonesia's economy is growing by leaps and bounds, where banking is very supportive financing of economic activities in order to meet the needs of Indonesian society. Bank as one of the business entity that provides loans to communities in the form of loans. Each implementation agreement on bank credit, is always associated with the presence of collateral, the collateral which was born in the credit agreement is already an agreement between the parties to bind themselves to each other in a credit agreement by means of a guarantee (collateral).

In the credit agreement guarantees delivery of goods which often occurs in the form of immovable goods (land). Mortgage is very important in the credit agreement for creditors, because with the provision of such security rights, creditors get the right key to a loan repayment of the credit for the result of the sale of goods as collateral. Legal Basis Execution for Mortgage regulated in Act No. 4 of 1996 on Mortgage of Land

\footnotetext{
${ }^{1}$ Students of Master Program (S2) in Notary Law Faculty of Law Universitas Islam Sultan Agung Semarang email eliza.arsenal@gmail.com.

2 Students of Master of Law, Faculty of Law, Universitas Islam Sultan Agung email rya_rizqi@yahoo.com

${ }^{3}$ Lecturer of Faculty of Law Unissula Semarang email endah.w@unissula.ac.id
} 
along Objects Relating to Land Article 20, where Article is known that basically the execution of land encumbered with Mortgage can be implemented through 2 ways:

- Auction pursuant to Article 6 UUHT ie if the debtor in default, the holder of the first Mortgage has the right to sell the object Encumbrance on kekusaan itself through a public auction, and take repayment of its receivable from the sale proceeds.

- Auction pursuant to Article 20 Paragraph 1 Letter b conjunction with Article 14, paragraph 2, states that the certificate has the power executorial Mortgage sebagaimna case with a court decision that has had permanent legal force.

Executorial contained in the Certificate of Mortgage accordance with title that include the words "For the justice Based on God" has executorial power equal to a court decision that has gained legal force along over land rights, the sale of objects collateral can be done immediately. ${ }^{4}$

\section{Research Methods}

In this study, the method used is the method of normative legal approach. Yuridicnormative research method is a procedure of scientific research to find out the truth based on scientific logic of normative side. ${ }^{5}$ The research is normative juridical research type, so the approach used in this study using the approach of legislation, which can be attributed to Act No. 4 of 1996 on Mortgage and use the existing library materials. In this approach is used to examine in depth about the execution of the object of Mortgage as loan collateral.

Types and sources of data used by the primary data or processing of library materials that have legally binding force and secondary data through information from parties associated with the title of author. Techniques in data collection using specific data collection tool that is guided by the study of literature and data obtained from stakeholders through interviews. Data analysis with qualitative descriptive analysis method, can then be analyzed to obtain clarity in solving problems and in drawing conclusions using deductive methods are then drawn conclusions for answer the problems. $^{6}$

\section{Results And Discussion}

\subsection{Execution of objects Mortgage as loan collateral at PT BPR Gunung Rizki Pusaka Utama Semarang.}

Bank as one of the business entity that provides loans to communities in the form of loans. In Act No. 10 of 1998 on the Amendment of Act No. 7 of 1992 concerning Banking Article 1 Clause 11 is the credit are:

\footnotetext{
4 M. Bahsan 2007 Hukum Jaminan dan Jaminan Kredit Perbankan Indonesia Jakarta : PT RajaGrafindo Persada, p 25.

5Jonny Ibrahim 2012 Teori dan Metodologi Penelitian Hukum Normatif Malang : Banyumedia Publising P 57.

${ }^{6}$ Bambang Sugogono 2003 Metode Penelitian Hukum Jakarta : Raja Grafindo Persada p 119.
} 
"The provision of cash or equivalent, based on the approval or the borrowing and lending between banks and other parties who require the borrower to repay the debt after a certain period denagn interest."

In accepting credit application the Bank needs to do the analysis in advance of the loan application, while the analysis conducted by the Bank shall include the following: ${ }^{7}$ Charater; Capacity (ability); Capital; Collateral; Condition (state)

Each implementation agreement on bank credit, is always associated with the presence of collateral, the collateral which was born in the credit agreement is already an agreement between the parties to bind themselves to each other in a credit agreement by means of a guarantee (collateral).

The position of general guarantees can be set in the Civil Code Section 1131 which stated that: "Everything that moves goods and immovable belonging to the debtor, both existing or that there will be, a guarantee to the engagements of the debtor's individual".

In the credit agreement guarantees delivery of goods which often occurs in the form of immovable goods (land). Based on Act No. 4 of 1996 regulating the Mortgage of Land along Objects Relating to Land. Understanding Mortgage in Article 1 Paragraph 1 of Act No. 4 of 1996 is:

"Mortgage on land and objects relating to soil, hereinafter called Mortgage, is a security interest that is charged on land rights as stipulated in Act No. 5 of 1960 on Basic Regulation of Agrarian, following or not the following other objects that are installed on the ground, for the repayment of certain debt, which gives the preferred position to certain creditors to other creditors ".

In explanation of the Act Encumbrance explained that the land rights security institutions are strong, where traits-characteristics are: ${ }^{8}$

- Provide preferred position to its holder.

- Always follow the object secured in the hands of whoever the object is.

- Meet the principle of specialty and publicity so as to bind third parties and provide legal certainty to the parties concerned.

- Easy and sure execution.

Banks provide credit at risk so that banks are required to be observated in analyzing credit to be given to be able to minimize the potential loss to the bank. Therefore, banks are required to observe the principle of a healthy credit, among others: ${ }^{9}$

- Banks are not allowed to extend credit without a written agreement.

- Banks are not allowed to giving out credits to businesses who from the beginning has been considered less healthy and will bring harm.

\footnotetext{
7 Abdulkadir Muhammad 2000 Segi Hukum Lembaga Keuangan dan Pembiayaan Bandung : Citra Aditya Bakti p 82.

${ }^{8}$ Jawade Hafidz dan Fadhilah Sundah, Implementasi Kekuatan Eksekutorial terhadap Hak Tanggungan Dalam Rangka Penyelesaian Kredit Macet Berdasarkan Akta yang Telah dibuat oleh $\begin{array}{llllll}\text { Notaris Jurnal Akta Vol } & 4 & \text { No } & 2 & \text { (2017), }\end{array}$ Jurnal.Unissula.ac.id/index.php/akta/article/viewfile/1799/1348.

Publish Date June 10, 2017, Pg 291.

${ }^{9}$ Mohammed Djumhana Op.cit p 447.
} 
- Banks are not allowed to give credit for the purchase of shares and working capital in the framework of the activity of buying and selling shares.

- Give credit exceeded the legal lending limit (legal lending limit).

In debts are secured by the Mortgage, if the debtor's breach of contract execution was carried out through a civil lawsuit under the Law of Civil Procedures. As for the socalled execution Encumbrance is: ${ }^{10}$ "If the debtor in default then the object Encumbrance sold through public auction in accordance with procedures specified in the regulations Legislation applicable and holders of Mortgage reserves the right to take all or part of the proceeds to the repayment of loans, with the right to precede rather than other creditors."

Banks are generally looking for solutions to save in order to avoid credit loan bad credit, namely by: ${ }^{11}$

- Rescheduling.

That changes regarding credit terms and payment schedule or the time period including a grace period, both include changes in the installment amount or not.

- Terms return (reconditioning).

Ie partial or total change in credit terms are not limited to changes in payment schedules, libertine time, and or other requirements as far as not relating to changes maksmimum credit balance and the conversion of all or part of the loans to investment banks.

- Realignment (restructuring).

That change in the terms of credit in the form of investment of bank funds, and or conversion of all or part of interest arrears into a new loan principal and or conversion of all or part of the credit to investment in the development of the company.

If such measures can not provide the expected results as it's the last alternative that can be taken by the creditor to the debtor is executing Mortgage which is to guarantee payment for the settlement of credit. So that with the execution of the security object Encumbrance then creditors will receive repayment of loans from borrowers.

Prior to the execution of Encumbrance, PT BPR Gunung Rizki Pusaka Utama Semarang give warning letters to borrowers who have trouble doing credit payment obligations. Warning letter is a notice from the creditor to the debtor of the obligation of repayment or repayment of debt, with interest. The notification letter sent by the Bank as much as three times in a row. If, after the debtor receives notification that the third but uncooperative debtors and also unable to pay or repay its debt obligations. Warning letters that have been sent to the debtor a letter of summons. The summons letter is very important in the execution of the object Mortgage as loan collateral at PT BPR Gunung Rizki Pusaka Utama Semarang.

\footnotetext{
${ }^{10}$ Purwahid Patrik dan Kashadi 2009 Hukum Jaminan Semarang : Badan Penerbit Universitas Diponegoro, p.160.

${ }^{11}$ Mohammed Djumhana Op.cit., p 487.
} 
Procedures for Mortgage execution provided for in Article 20 of the Act No. 4 of 1996 regulating the Mortgage of Land along Objects Relating to Land. Execution Mortgage can be done in three ways: ${ }^{12}$

- Rights holders Encumbrance first to sell Encumbrance on its own power through a public tender as referred to in Article 6, that is, if the debtor in default, the holder of Encumbrance first has the right to sell the object Encumbrance on kekusaan itself through a public auction, and take repayment of its receivables from the sales results.

- Execution of title contained in the Encumbrance certificate, as referred to in Article 14, paragraph 2. Title (head decision) listed on Encumbrance certificate is meant to emphasize the strength executorial on Encumbrance certificate, so that if the debtor in default, ready to be executed as well as a court ruling which has permanent legal power, through procedures and using executie parate institutions in accordance with the Civil procedure Code.

- Execution under the hand

Execution under the hand is the object of sales conducted by the Mortgage Mortgage providers, by agreement with the holders of Encumbrance, if in this way will obtain the highest price.

The authority of PT BPR Gunung Rizki Pusaka Utama Semarang in execution objects in a way that is Encumbrance, Parate execution is if the debtor defaults, the lender can carry out the execution of security object without having to ask the fiat of the President of the Court, without having to follow the rules in the Criminal Procedure. For that there is the rule itself does not need no prior seizure, does not need to involve bailiffs and therefore the procedure is easier and cheaper cost. ${ }^{13}$

Rights in Article 6 of Act No. 4 of 1996 regulating the Mortgage of Land along Items Related to This land is one manifestation of the notch preferably owned by the holder of Mortgage or Encumbrance first in case there is more than one Mortgage holders. Such rights are based on the promise given by the grantor Encumbrance that if the debtor in default, the holder of Mortgage entitled to sell the object Encumbrance through public auction without the approval again from lender Mortgage and subsequently take the settlement receivables from the sales proceeds over precedence over the other creditors. The rest of the proceeds from the sale shall remain the Mortgage providers. ${ }^{14}$

Thus the Mortgage holders or creditors can directly ask the Auction Office of the State to be able to sell at a public auction Encumbrance object if the debtor in default. The ordinance is the most easy and quick, so that the debtor does not have to submit the petition to the Court.

\footnotetext{
${ }^{12}$ Salim HS 2016 Perkembangan Hukum Jaminan di Indonesia (Ninth Edition) Jakarta : PT Raja Grafindo Persada, p.190-191.

${ }^{13}$ Herowati Poesoko 2013 Dinamika Hukum Parate Executie Obyek Hak Tanggungan Yogyakarta : Aswaja Presindo, p 195.

${ }^{14}$ Ibid., $p 164$
} 


\subsection{The obstacles that occur in the execution of the object of Mortgage as loan collateral at PT BPR Gunung Rizki Pusaka Utama Semarang.}

The factors causing their problem loans, namely: ${ }^{15}$

- Failure in the debtor's business

- The decline in economic activity and high lending rates

- Utilization of the banking world competition climate unhealthy by the responsible debtor

- Their plight debtor company.

In the execution of the object Rights Tangungan as loan collateral common barriers include: ${ }^{16}$

- Objects belonging to a third party guarantee

In principle, the guarantees will be secured by the debitor is his property, but did not rule out the possibility that the object of the guarantee of a third party. Where the third party has authorized for installation guarantee. In the execution of the collateral object, its third party execution blocking occurs against the collateral object, the grounds in question never authorize the debtor to pledge their land. If it happens that authorization is done by bedrog, dwalling, dwang, and unduemfluence.

- The collateral has not been registered

Goods secured on banking institutions must be registered collateral. However, in reality, much of the credit given to customers without registration. Registration guarantees for Encumbrance conducted by the National Land Agency.

- Lack of good faith of the debtor

The lack of good faith is a lack or absence of the debtor's willingness to pay off the forest, although concerned with money. Debtor himself thought that we were invited to KP2LN to conduct the auction of the collateral objects. He argues that the collateral value of objects smaller than the number of debts.

\subsection{The solution adopted in overcoming obstacles to the execution of the object Mortgage as loan collateral at PT BPR Gunung Rizki Pusaka Utama Semarang.}

Some of the solutions adopted to overcome these obstacles are:

a. Analysis of a debtor must thoroughly selective and mengatahui the character / character, business, owner of collateral, and the ability of borrowers to be the case if the debtor in default will be easier in the execution of such guarantee.

b. The insurance certificate is secured by the debtor to the creditor should be registered Encumbrance in the National Land Agency (BPN), for the registration of the Mortgage will be easier to make the auction process if the debtor in default.

\footnotetext{
${ }^{15}$ Sukarmi dan Gilang Bayuaji,Pelaksanaan Penyelesaian Kredit Macet yang Diikat dengan Hak Tanggungan di PT Bank Tabungan Pensiunan nasional Mitra Usaha Rakyat Cabang Tegal, Jurnal Akta Vol 4 No 1 (2017), jurnal.unissula.ac.id/index.php/akta/article/download/1534/1184 Date of issue July 28, 2017, p. 11.

${ }^{16}$ Salim HS. 2016. op.cit. p 275-276.
} 
c. Awareness to the debtor to pay off the loan in a timely manner according to the due date agreed in the credit agreement.

\section{Clossing}

\subsection{Conclusion}

Conclusions based on the results of research and discussion that has been described above is as follows:

- Their execution on the ground Mortgage can provide guarantees and legal protection against creditors for the recovery of receivables if the debtor can not fulfill its obligations or the debtor defaults in making payments or repayment of its receivables. Implementation of Execution Objects Tanggugan Rights as loan collateral at PT BPR Gunung Rizki Pusaka Utama Semarang do with Parate execution intended to be more efficient and faster in obtaining repayment of its receivables.

- The obstacles that occur in the object execution Mortgage as loan collateral at PT BPR Gunung Rizki Pusaka Utama Semarang is, objects belonging to a third party guarantee, assurance Goods not yet been registered, and Lack of good faith of the debtor.

- The solution adopted in dealing with the implementation of the object of Mortgage as loan collateral at PT BPR Gunung Rizki Pusaka Utama Semarang is, an analysis of the debtor must thoroughly selective and mengatahui the character / character, business, owner of collateral, and the ability of borrowers so that if the debtor occurred breach of contract (default ) will be easier to carry out the execution of such guarantee, guarantee in the form of certificates that are secured by the debtor to the creditor should be registered Encumbrance in the National Land Agency (BPN), Awareness to the debtor to pay off the loan in a timely manner according to the due date has been agreed in the credit agreement.

\subsection{Suggestion}

- Debtor in paying credit obligations can be timely in accordance with the due date agreed in the credit agreement in order to avoid execution debtor Rights.

- To reduce the occurrence of obstacles to the execution object of Mortgage as loan collateral should the PT BPR Gunung Rizki Pusaka Utama Semarang should be more careful and selective in conducting an assessment of the debtor, for example, a character, the owner of collateral and the debtor's business and the ability and willingness of the debtor in doing his duty.

- Creditors PT BPR Gunung Rizki Pusaka Utama Semarang in giving credit to the debtor should provide an assessment of collateral that will be pledged to have a higher value than the value of their loans, because in case of execution, the object of the guarantee can be insufficient for repayment of loans.

\section{Bibliography}


[1] Abdulkadir Muhammad. 2000. Segi Hukum Lembaga Keuangan dan Pembiayaan. Bandung : Citra Aditya Bakti.

[2] Bambang Sugogono. 2003. Metode Penelitian Hukum. Jakarta: Raja Grafindo Persada.

[3] Herowati Poesoko 2013 Dinamika Hukum Parate Executie Obyek Hak Tanggungan Yogyakarta : Aswaja Presindo.

[4] Jonny Ibrahim 2012 Teori dan Metodologi Penelitian Hukum Normatif Malang : Banyumedia Publising.

[5] M Bahsan 2007 Hukum Jaminan dan Jaminan Kredit Perbankan Indonesia Jakarta : PT RajaGrafindo Persada.

[6] Muhamad Djumhana 2012 Hukum Perbankan di Indonesia Bandung : PT Cipta Aditya Bakti (Cetakan Ke Enam).

[7] Purwahid Patrik dan Kashadi 2009 Hukum Jaminan Semarang : Badan Penerbit Universitas Diponegoro

[8] Salim HS 2016 Perkembangan Hukum Jaminan di Indonesia (ninth edition) Jakarta: PT Raja Grafindo Persada.

[9] Code of Civil law

[10] Act No 4 of 1996 on Mortgage of Land along Objects Relating to Land

[11] Act No 10 Of 1998 on the Amendment of Uandang Number 7 of 1992 concerning Banking

[12] Jawade Hafidz dan Fadhilah Sundah, Implementasi Kekuatan Eksekutorial terhadap Hak Tanggungan Dalam Rangka Penyelesaian Kredit Macet Berdasarkan Akta yang Telah dibuat oleh Notaris Jurnal Akta Vol 4 No 2 (2017), jurnal.unissula.ac.id/index.php/akta/article/viewfile/1799/1348. Publish on June 10, 2017.

[13] Sukarmi dan Gilang Bayuaji, Pelaksanaan Penyelesaian Kredit Macet yang Diikat dengan Hak Tanggungan di PT Bank Tabungan Pensiunan nasional Mitra Usaha Rakyat Cabang Tegal, Jurnal Akta Vol 4 No 1 (2017), jurnal.unissula.ac.id/index.php/akta/article/download/1534/1184. Published on July 28, 2017. 